\title{
PENGEMBANGAN MODUL PRAKTIKUM FISIKA MODEL GUIDE INQUIRY BERBASIS COMPUTERIZED EXPERIMENT TOOL (CET) UNTUK PEMBENTUKAN KARAKTER ILMIAH SISWA
}

\author{
${\text { Johri Sabaryati }{ }^{*} \text {, Ni Wayan Sri Darmayanti }}^{2}$ \\ ${ }^{1 *} \& 2$ Dosen Progran Studi Pendidikan Fisika Universitas Muhammadiyah Mataram \\ Corresponding author : \\ E-mail : joyafarashy@gmail.com
}

Diterima 2 Juli 2018, Disetujui 5 Juli 2018

\begin{abstract}
ABSTRAK
Penelitian ini bertujuan untuk : (1) Mengembangkan modul praktikum model guided inquiry berbasis computerized experiment tool (CET) untuk pembentukan karakter ilmiah siswa layak digunakan. (2) Mengetahui kualitas modul praktikum model guided inquiry berbasis computerized experiment tool (CET) untuk pembentukan karakter ilmiah siswa. Secara umum peneltian ini melalui 3 tahap utama, yaitu: (1) studi pendahuluan, (2) dan pembuatan dan pengembangan produk, (3) evaluasi. Tahapan pertama dan kedua telah dilakukan, sedangkan tahap ketiga yang berupa kegiatan evaluasi sampai saat ini sudah dilakukan kegiatan validasi ahli dan penilaian pendidik. Kemudian juga telah dilakukan uji coba terbatas di MA Nurul Haramain Narmada. Berdasarkan hasil penelitian yang telah dilakukan, maka dapat disimpulkan sementara sebagai berikut: (1) Berdasarkan hasil validasi ahli dan penilaian pendidik dapat disimpulkan bahwa produk modul praktikum model guided inquiry berbasis computerized experiment tool (CET) yang telah dikembangkan telah layak untuk digunakan. (2) Berdasarkan hasil uji coba terbatas diketahui bahwa produk hasil pengembangan dapat meningkatkan karakter tanggung jawab, kreatif dan teliti. Karakter yang paling tinggi peningkatannya adalah karakter tanggung jawab.
\end{abstract}

Kata kunci: Modul, Guided Inquiry, CET, Karakter IImiah.

\section{PENDAHULUAN}

Penerapan pendekatan saintifik dalam proses pembelajaran merupakan bagian dari keterampilan proses sains meliputi kegiatankegiatan seperti observasi, bertanya, bernalar, dan mengkomunikasikan, seperti yang dikemukakan oleh (Brotherton,1995), (Dahar,2012) dan (Isnaini,2014). Pengalaman belajar tersebut dapat dibelajarkan kepada siswa melalui model pembelajaran berbasis inkuiri (Faizin, 2016). Pembelajaran fisika dengan model inkuri (guided inquiry) berkaitan dengan karakter ilmiah yang dapat ditumbuhkan melalui kegiatan pengamatan, bukan hanya dengan teori . Kegiatan pengamatan melalui eksperimen atau pemodelan memiliki peran motivasi dalam kegiatan belajar siswa, mengurangi miskonsepsi siswa dan memberi kesempatan kepada siswa mengembangkan sejumlah keterampilannya serta dapat meningkatkan kualitas belajar siswa (Rosli, 2017).

$\mathrm{Di}$ tingkat sekolah menengah umumnya pembelajaran sains dalam hal ini fisika dibagi menjadi dua bagian besar yaitu konteks fisika sebagai produk dan sebagai proses. Konteks fisika sebagai produk adalah proses pembelajaran mengenai fakta, teori, prinsip dan hukum alam; konteksnya sebagai proses adalah kegiatan pengembangan kemampuan ilmiah dan pemecahan masalah fisika (Sumintono, 2007). Fisika sebagai mata pelajaran yang menghasilkan proses dan produk. Oleh karena itu tidak boleh mengesampingkan proses ditemukannya konsep. Hal ini terjadi karena siswa dapat mengintegrasikan konsep, prinsip dan hukum yang dipelajari, tidak hanya mengandalkan daya imajinasi dan pemakaian matematis. Konsep fisika dapat diperlihatkan dengan mudah, interaktif dan murah dengan memperagakan menggunakan alat peraga (Arsyad,2015).

Namun penggunaan laboratorium dalam kegiatan praktikum masih rendah karena keterbatasan alat dan bahan praktikum serta rendahnya kemampuan guru dalam melaksanakan kegiatan praktikum. Hal ini berdasarkan hasil penelitian yang telah dilakukan oleh Sumintono (2010) di Cimahi, serta peneltian saya dan Nanang Rahman (2016) di kabupaten Lombok barat. Menunjukan gejala bahwa kemampuan guru dalam mengelola kegiatan laboratorium masih kurang, dan frekuensi kegiatan praktikum masih jarang dilakukan. Hal ini diperkuat pada penelitian evaluasi kesiapan guru fisika Se-Kota Mataram provinsi Nusa Tenggara Barat dalam kegiatan laboratorium; sarana prasarana laboratorium di Kota Mataram 36.9\% dalam kategori baik, 26.2\% 
berkategori cukup baik dan $36.9 \%$ dalam kategori kurang pada Penelitian M. isnani (2014).

Berdasarkan data yang diperoleh dari wawancara dengan guru MA NW Nurul Haramain Narmada di Kabupaten Lombok Barat menyatakan bahwa kegiatan praktikum jarang dilakukan karena keterbatasan alat dan bahan yang tersedia. Pelaksanaan praktikum dapat berjalan dengan baik apabila semua alat dan bahan yang ada pada modul praktikum tersedia dalam jumlah yang cukup dan dalam kondisi baik, sedangkan pada kenyataan di sekolah bahwa alat dan bahan yang tersedia jumlahnya terbatas.

Dalam proses pembelajaran yang kurang aktif melibatkan siswa, dimana siswa hanya menerima konsep yang diberikan guru tanpa pernah membuktikan konsep tersebut. Hal ini mengakibatkan tidak berkembangnya keterampilan proses sains siswa. Sehingga dibutuhkan alat peraga yang memadai untuk menunjang kegiatan proses pembelajaran (Kurnianto, dkk. 2010).

Dengan perkembangan teknologi yang begitu cepat, kegiatan praktikum fisika seharusnya menjadi lebih efektif dan berkualitas. Pemanfaatan teknologi misalnya komputer dapat membantu perancangan alat peraga yang memiliki tingkat ketelitian dan efisiensi waktu dalam kegiatan praktikum, serta dapat menunjukkan fenomena sehari-hari yang ilmiah sehingga dapat membantu siswa mencapai suatu pemahaman mendalam pada pokok bahasan yang diberikan serta membangun karakter ilmiah siswa (Chia-Yu Liu, 2017).

Alat peraga yang dikembangkan diharapkan dapat memvisualkan materi yang sedang dipelajari. Dengan menggunakan alat peraga, tentunya siswa dapat melihat langsung bagaimana proses yang terjadi di dalamnya sehingga akan lebih memahami konsep materi. Namun selain kurangnya alat praktikum, disekolah juga mengalami keterbatasan dalam modul praktikum (Hasbi, 2015).

Fokus utama pada kegiatan di modul meliputi kemampuan untuk melakukan identifikasi variabel, mengontrol variabel dan menghitung data. Hal ini merupakan ciri khusus dari tahap guided inquiry (Wenning, 2005). Oleh karena itu peneliti tertarik untuk mengembangkan modul praktikum model guided inquiry berbasis computerized experiment tool (CET) untuk membentuk karakter ilmiah siswa. Untuk menghasilkan proses belajar yang baik, asyik, menarik, interaktif, produktif dan konstruktif bagi guru dan siswa agar suasana belajar lebih hidup.

\section{METODE PENELITIAN}

Tahapan Penelitian Pengembangan Prosedur pengembangan

digunakan dalam penelitian dan pengembangan ini adalah pengembangan secara prosedural dimana langkah-langkahnya dijelaskan secara kongkrit dan rinci. Modul Praktikum Model Guided Inquiry Berbasis Computerized Experiment Tool yang dikembangkan hanya terbatas pada materi pokok Gerak. Modul praktikum dilengkapi dengan set alat ekperimen gerak yang terdiri dari bidang miring, sensor cahaya, Arduino, dan program computer untuk menampilkan data hasil percobaan. Prosedur pengembangan yang dilakukan mengacu kepada prosedur Borg \& Galls.

\section{Lokasi Penelitian (Uji Coba Produk)}

Subjek penelitian untuk uji coba produk yang dikembangkan dalam penelitian ini adalah siswa MA Nurul Haramain Narmada di Kabupaten Lombok Barat yang terdiri atas 19 siswa.

\section{Teknik Pengumpulan Data}

Untuk menghasilkan produk yang berkualitas diperlukan teknik pengumpulan data dan instrumen yang mampu menggali data yang diperlukan dalam pengembangan Modul Praktikum Model Guided Inquiry Berbasis Computerized Experiment Tool. Teknik pengumpulan data dengan observasi dan angket. Instrumen yang digunakan untuk mengumpulkan data pada penelitian ini berupa lembar kuesioner kelayakan produk (alat dan modul praktikum), lembar observasi dan angket karakter.

\section{a) Analisis Data}

Kegiatan uji coba ini memperoleh 2 jenis data yaitu data kuantitatif dan kualitatif. Data kualitatif berupa saran dan kritikan oleh ahli media, ahli materi, dan pendidik untuk memperbaiki modul praktikum dan set alat eksperimen yang telah dikembangkan. Sedangkan data kuantitatif berupa hasil penilaian produk, hasil observasi dan angket karakter.

\section{b) Analisis Lembar kuesioner kelayakan produk}

Dalam penelitian ini lembar kuesioner kelayakan produk diberikan kepada ahli dan pendidik. Data yang diperoleh dari lembar kuesioner diubah menjadi data interval.

Hasil penilaian oleh ahli dan pendidik reratanya memberikan hasil akhir "B". Pada penelitian ini hasil akhir "B" termasuk kategori "Baik", maka produk pengembangan yang berupa perangkat Modul Praktikum Model Guided Inquiry Berbasis Computerized Experiment Tool dan set alat ekperimen untuk membentuk karakter ilmiah siswa ini sudah dianggap layak digunakan.

c) Analisis Instrumen untuk mengukur karakter

1) Lembar observasi pembentukan karakter 
Lembar observasi pembentukan karakter dianalisis dengan melihat hasil rerata karakter pada setiap uji coba produk. Deskripsi pembentukan karakter pada setiap kali pertemuan dengan melihat kecenderungan peningkatan pembentukan karakter pada grafik pembentukan karakter teliti, tangung jawab, dan kreatif.

\section{2) Analisis Angket karakter}

Angket karakter digunakan pada awal dan akhir proses pembelajaran untuk melihat karakter siswa yang dikembangkan. Angket ini menggunakan angket Likert skala lima yaitu: selalu, sering, kadang-kadang, jarang dan tidak pernah. Untuk mengetahui selisih nilai pre-test dan post-test dihitung dengan menggunakan teknik gain standar. Rumus untuk menentukan gain standar adalah sebagai berikut : Hake (1998: 3)

$$
\begin{gathered}
\text { gain }=\frac{S_{\text {post }} S_{\text {pre }}}{100-S_{\text {pre }}} \\
\text { Keterangan: } \\
g(\text { gain) = gain } \\
S_{\text {pre }}=\text { skor awal } \\
S_{\text {post }}=\text { skor akhir }
\end{gathered}
$$

Adapun penentuan peningkatan pembentukan karakter siswa terdapat dalam tabel 1

Tabel 1. Tingkatan Gain Standar

\begin{tabular}{|l|c|}
\hline Nilai gain & Keterangan \\
\hline $\mathrm{g} \geq 0,7$ & Tinggi \\
\hline $0,7>\mathrm{g} \geq 0,3$ & Sedang \\
\hline $\mathrm{g}<0,3$ & Rendah \\
\hline
\end{tabular}

\section{HASIL PENELITIAN}

Data Hasil Validasi dan Penilaian Produk

Penelitian pengembangan modul praktikum ini memperoleh data hasil validasi dari data hasil validasi oleh ahli materi, media dan pendidik. Didalam data ini dilengkapi dengan masukan serta komentar terhadap Modul Praktikum, set alat eksperimen, angket dan lembar observasi karakter.

Validasi ahli dilakukan untuk memberikan nilai dan menentukan kelayakan produk yang telah dikembangkan. Sedangkan Penilaian dilakukan oleh pendidik untuk mendapatkan nilai terhadap perangkat modul yang dikembangkan. Sehingga diperoleh komentar dan saran, baik secara tertulis maupun lisan.

\section{a. Modul Praktikum Model Guided Inquiry Berbasis CET}

Validasi dan penilaian juga bertujuan untuk memperoleh komentar dan saran, baik secara tertulis maupun lisan dengan cara berdiskusi tentang modul praktikum model guided inquiry berbasis CET. Rekap hasil validasi oleh ahli dan pendidik

Tabel 2. Hasil penilaian ahli dan pendidik

\begin{tabular}{|c|l|c|c|}
\hline No & \multicolumn{1}{|c|}{ Penilai } & Total & Skor \\
\hline 1 & Ahli I & 68 & A \\
\hline 2 & Ahli II & 59 & B \\
\hline 3 & Pendidik I & 71 & A \\
\hline 4 & Pendidik II & 66 & A \\
\hline \multicolumn{4}{|c|}{ Berdasarkan hasil penilaian yang }
\end{tabular}

dilakukan oleh ahli dan pendidik terhadap modul praktikum, maka dapat dikategorikan layak digunakan.

\section{b. Set Alat eksperimen}

Validasi dan penilaian terhadap set alat ekperimen karakter terdiri atas beberapa komponen yaitu keterkaitan dengan modul, bahan dan estetika. Seperti pada table 3

Tabel 3. Hasil penilaian alat oleh ahli dan pendidik

\begin{tabular}{|c|l|c|c|}
\hline No & \multicolumn{1}{|c|}{ Penilai } & Total & Skor \\
\hline 1 & Ahli I & 43 & A \\
\hline 2 & Ahli II & 34 & B \\
\hline 3 & Pendidik I & 42 & A \\
\hline 4 & Pendidik II & 46 & A \\
\hline
\end{tabular}

\section{c. Angket karakter}

Validasi dan penilaian terhadap angket karakter terdiri atas beberapa komponen yaitu: materi karakter, konstruksi dan kebahasaan. Data hasil penilaiany a berupa skor dikonversikan menjadi nilai skala lima. Data hasil penilaian oleh ahli dan pendidik terhadap angket dan lembar observasi karakter peserta didik akan dipaparkan sebagai berikut:

Tabel 4. Data hasil penilaian angket dan lembar observasi karakter oleh ahli dan pendidik

\begin{tabular}{|c|l|c|c|}
\hline No & Validator & Total & Skor \\
\hline 1 & Ahli I & 35 & A \\
\hline 2 & Ahli II & 35 & A \\
\hline \multicolumn{2}{|c|}{ Berdasarkan hasil penilaian yang }
\end{tabular}

dilakukan oleh ahli dan pendidik terhadap angket dan lembar observasi karakter, maka dapat dikategorikan sudah layak digunakan.

\section{Hasil Uji CobaTerbatas}

Uji coba terbatas dilakukan di MA Nurul Haramain dengan jumlah subjek uji coba sebanyak 19 siswa. Hasil uji coba terbatas yang telah dilakukan mendapatkan 2 data yaitu data tanggapan siswa terhadap produk yang telah diujicobakan..

Angket karakter ini digunakan untuk mengukur pembentukan karakter ilmiah siswa berdasarkan pada data. Karakter yang dibentuk dalam penelitian ini adalah tanggung jawab, kreatif, dan teliti.

Data rerata pembetukan karakter pada uji coba terbatas dapat dilihat dari data angket yang 
diberikan sebelum penggunaan produk dan setelah penggunaan produk seperti tabel 7 .

Tabel 5. Rerata Pretest dan Postest pembetukan karakter pada uji coba terbatas

\begin{tabular}{|l|c|c|c|c|}
\hline Karakter & $\begin{array}{l}\text { Pre } \\
\text { test }\end{array}$ & $\begin{array}{l}\text { Pos } \\
\text { test }\end{array}$ & $\begin{array}{l}\text { Gain } \\
\text { standar }\end{array}$ & Kriteria \\
\hline $\begin{array}{l}\text { Tanggung } \\
\text { Jawab }\end{array}$ & 197 & 255 & 0,7 & Tinggi \\
\hline Kreatif & 105 & 151 & 0,5 & Sedang \\
\hline Teliti & 162 & 227 & 0,5 & Sedang \\
\hline
\end{tabular}

Berdasarkan tabel 5 di atas, maka dapat disimpulkan bahwa pembentukan karakter tanggung jawab memiliki nilai yang besar dibandingkan yang lain. Hal ini karena modul praktikum model guided inquiry berbasis CET terdiri atas rangkaian yang alatnya sangat sensitivitas. Sehingga siswa sangat berhati-hati dan bertanggung jawab dalam penggunaan alatnya. Kareana pengukuran dengan menggunakan sensor dan program computer. Maka set alat eksperimen berbasis CET pembuktian sebuah teori mudah, jelas dan tepat.

\section{KESIMPULAN}

Berdasarkan hasil penelitian yang telah dilakukan, maka dapat disimpulkan sebagai berikut:

1. Berdasarkan hasil validasi ahli dan penilaian pendidik dapat disimpulkan bahwa produk modul praktikum model guided inquiry berbasis CET yang telah dikembangkan layak untuk digunakan.

2. Berdasarkan hasil uji coba terbatas bahwa modul model guided inquiry berbasis CET dapat meningkatkan karakter tanggung jawab, kreatif dan teliti. Karakter yang paling tinggi peningkatannya adalah karakter tanggung jawab.

\section{DAFTAR PUSTAKA}

Borg, W. R. \& Gall, M. D. (1983). Educational research: An introduction (4 th ed). New York: Longman Inc.

Bryce, T.G.K., J. McCall, J. MacGregor, I.J. Robertson, \& R.A.J. Weston. (1990). Techniques for Assesing Process Skills in Practical Science: Teacher's Guide. Oxford: Heinemann Educational Books. California State University. (2007). Effective Teaching. California: California State University Northtridge.

Darmiyati Zuchdi, Zuhdan Kunprasetya, Marzuki, et al. (2010). Pendidikan karakter dengan pendekatan komprehensif. Yogyakarta: UNY Press.

Depdiknas. (2006). Panduan Pengembangan Pembelajaran IPA Terpadu, SMP/MTs.
Jakarta: Pusat Kurikulum Balitbang Diknas.

$\begin{array}{cl}\text { pembelajaran berdasarkan nilai- } \\ \text { nilai budaya untuk membentuk daya } \\ \text { saing dan karakter bangsa. Jakarta: } \\ \text { Depdiknas. } \\ \text { Salirawati, } \\ \text { D. (2001). Materi Pelatihan Kepala } \\ \text { Laboratorium Kimia bagi Guru-Guru } \\ \text { Kimia Kabupaten Kulon Progo. } \\ \text { Disampaikan di Laboratorium FMIPA } \\ \text { UNY Yogyakarta, } 1 \text { Oktober 2011. } \\ \text { Tatat Hartati, dkk. (2009). Productive } \\ \text { Pedagogy \& Subject Specific } \\ \text { Pedagogy.Bandung: } & \text { Universitas } \\ \text { Pendidikan Indonesia (UPI) Bandung }\end{array}$

